\title{
Clay Minerals Deposit of Halakabad (Sabzevar- Iran)
}

\author{
Seyed Mohammad Hashemi \\ Department of Geology, Mashhad branch, Islamic Azad University, Mashhad - Iran \\ E-mail: dhashemi@mshdiau.ac.ir
}

\begin{abstract}
Clay minerals are expanded in south of Sabzevar. They are identified with light color in the filed. The XRD and XRF chemical and mineralogical studies on the Clay minerals indicated that their main clay minerals are Kaolinite, Illite and Dickite. Pyrophyllite is minor clay mineral. Quartz and Sanidine non clay minerals are present with clay minerals .Ratio of Al2O3 is about 40 per cent, it is very good for industrial minerals .Volcanic rocks are origin clay minerals .Their composition are basic to acidic. In south of Sabzevar town there is a small part of these rocks available which include volcanic and volcaniclastic rocks .Geochemical and petrographic studies showed that their compositions are generally acidic and intermediates and are of Dacite and Rhyolite and Andesite rocks type that have changed into clay minerals.
\end{abstract}

Keywords - Volcanic rocks; Kaolinite; Industrial clay minerals; Sabzevar -Iran

\section{INTRODUCTION}

Next to the kaolinite deposit in Sabzevar has a rising importance to the Iran economy. It was found deposit is found in 1997 in the area of the South Sabzevar Halakabad region between the longitudes of $57^{\circ} 37^{\prime}$ and $57^{\circ} 39^{\prime} \quad \mathrm{E}$ and latitudes $35^{\circ} 57^{\prime}$ and $36^{\circ} \mathrm{N}$ in the Khorasan Razavi Province. It lays there in 1400 to 1440 meter above sea level. The result of detailed geological exploration work, which was carried out in the years 1997 to 2008, showed that the deposit has an exploitable reserve of more than 0.5 million tons of raw material.

The polarization microscopy, XRD, SEM and thermal analysis on the ore material from Sabzevar deposit taken in the year 2008 have been carried out at the Kansaran binaoold company of Iran, in order to find out a support method for a selected mining focused on pure Kaolinite, a high value raw material for many inland industry branches and for export.

\section{GeOlogicAl SETtings}

The deposit area is dominated by Cenozoic volcanosediments and Cenozoic volcanites (Karaj formation of Eocene: rhyolite, rhyolite-dacite, rhyolitic tuffs) and also sediments of Cenozoic with marl, conglomerate, sandstone, siltstone and shale. An intensive tectonic fault system shapes the landscape as well as the location of deposit. The different ore bodies, mostly in shape of lenses, are located along the marginal faults in the region (Fig.1).

The metasomatose and the hydrothermal changes started at the early of Cenozoic times[1]. The acidic volcanites covering siltstone and conglomerate built a resistant horizon for metasomatose.

\section{MINERALIZATION}

The mineralization is detected in certain zones after geological exploration. These different zones are distinguished as follows:

- Kaolinite-pyrophyllite ( $40 \%$ of kaolinite),

- Kaolinite-dickite,

- Alunite.

These types of minerals are characterized by the content of $\mathrm{Al} 2 \mathrm{O} 3$ [2]. At the moment it is extraordinary complicated to describe the exact development of stage-by-stage genesis of the deposit. But it is known that alunite was found only in contact to the Cenozoic shales and siltstones while the pure pyrophyllite occurrence is located next to the effusives and pyroclastic material. The different mineralization stages are given in Table 1.

\section{A. Kaolinite-Pyrophyllite}

Mineralogy composition of 1 type can be distinguished: Quartz - free kaolinitic pyrophyllite (with $40 \%$ of kaolinite). Type 1 is macroscopic one, described as a dense, white to dark grey or even green stone with low hardness. Some samples are marked by small quartz particles in whiteopaque stone[3]. Another hint is the relict structure of the former rhyolite. In addition some of them can be seen due to the occurrence of dark grey spots in a white opaque matrix. Under the polarization microscope pyrophyllite has white- 
yellow interferences, while kaolinite and dickite are mostly dark grey to black.

The distinctions between kaolinite and pyrophyllite and even the differences of all types can easily be shown. The pyrophyllite was detected in XRD analysis by the main reflection at $3.1 \AA(100 \%), 9.56 \AA(50 \%)$ and $4.33 \AA(40 \%)$ as found in graphs (Fig.3, 4). Nevertheless pyrophyllite (Fig. 4) is the dominating polytype. A different pyrophyllite generation is not yet proofed. These two polytypes of pyrophyllite are also seen by thermal analysis. They show reactions at $750^{\circ} \mathrm{C}$ and $850^{\circ} \mathrm{C}$ with a mass loss of $5.5-6 \%$. The pyrophyllite of Halakabad is developed as xenomorphic and sheeted particles by terms of morphology, seen by electronic microscopy in $<3 \mu \mathrm{m}$ fraction [4].

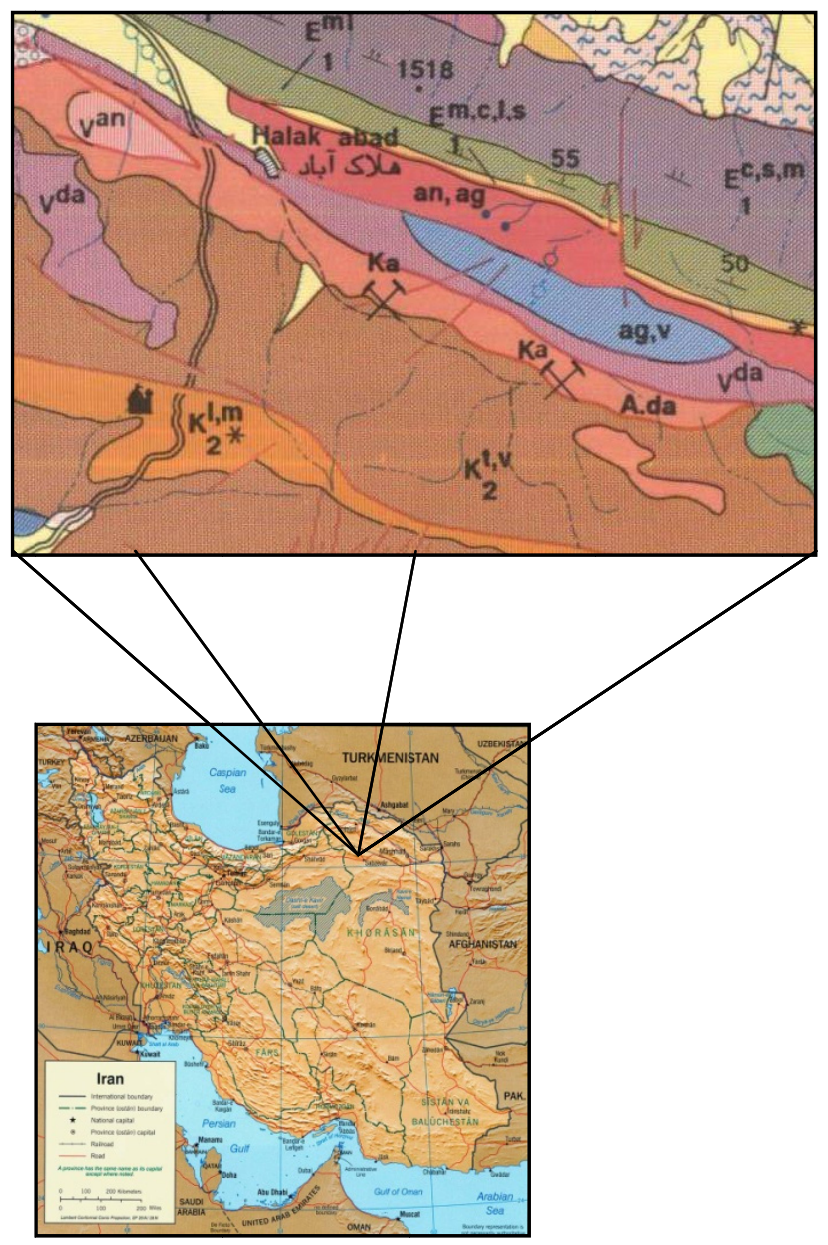

Fig.1: Geological setting of Halakabad Deposit

A.da: Altered dacite (Kaolinitized)

Kt.v : Green $t$ uff and andesite and dacite

TABLE I

DIFFERENT MINERALIZATION STAGES IN HALAKABAD DEPOSIT

\begin{tabular}{|l|l|l|}
\hline $\begin{array}{l}\text { Mineralization } \\
\text { stage }\end{array}$ & $\begin{array}{l}\text { Characteristic mineral } \\
\text { assemblage }\end{array}$ & $\begin{array}{l}\text { Forming } \\
\text { temperature } \\
\left({ }^{\circ} \mathbf{C}\right)\end{array}$ \\
\hline Kaolin & $\begin{array}{l}\text { Kaolinite, dickite and } \\
\text { quartz }\end{array}$ & $\sim 260$ \\
\hline Pyrophyllite & $\begin{array}{l}\text { Pyrophyllite, } \\
\text { kaolinite and quartz }\end{array}$ & $\sim 260-290$ \\
\hline Alunite & $\begin{array}{l}\text { Alunite, pyrophyllite } \\
\text { and diaspora }\end{array}$ & $\sim 290-320$ \\
\hline
\end{tabular}

\section{B. Kaolinite- Dickite}

This stone shows a light transparency, a low hardness and has White opaque, yellow and often green colors. By means of XRD and thermal analyses (kaolinite $\sim 500^{\circ} \mathrm{C}$ and dickite $\sim 650^{\circ} \mathrm{C}$ ) (Tab. 1) it is possible to make reports about the share of the minerals in the rock. It is also to be mentioned that the kaolin particles in $<3 \mu \mathrm{m}$ fraction mostly show pseudo-hexagonal morphology [5].

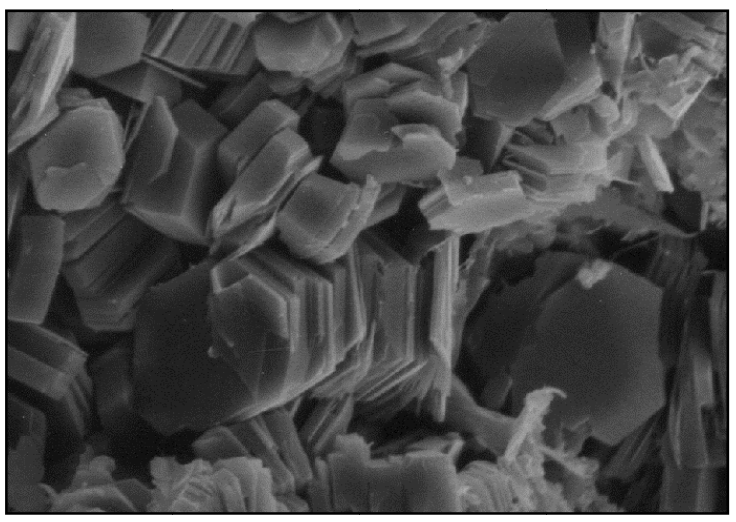

Fig.2: Kaolinite SEM photo

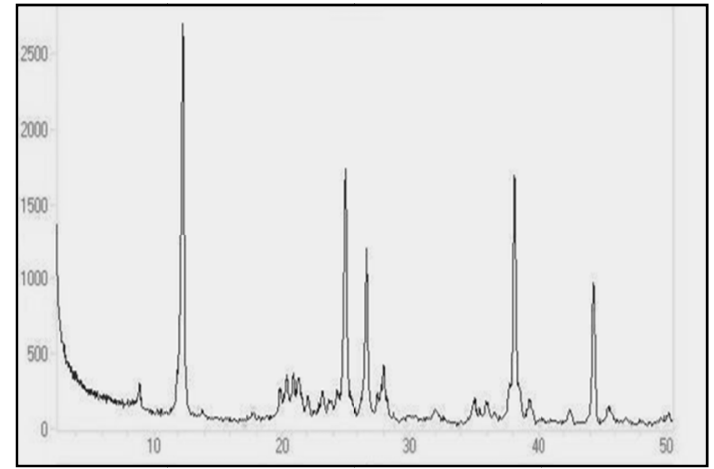

Fig.3. XRD - pattern of Kaolinite with Dickite

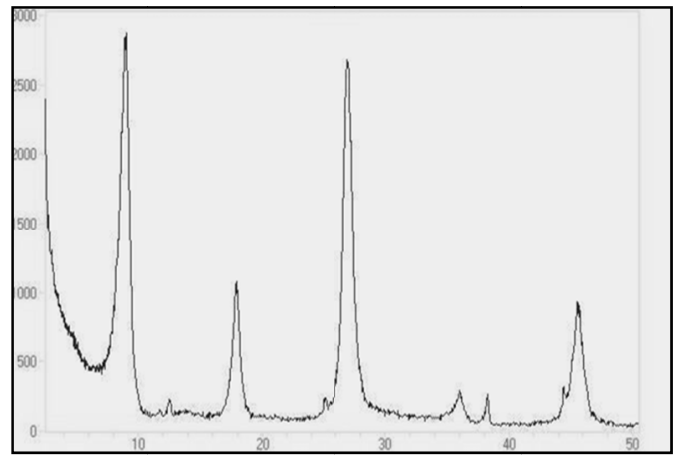

Fig.4. XRD-pattern of Pyrophyllite with Quartz and Dickite

\section{Alunite}

No more than 3 levels of headings should be used. All headings must be in 10pt font. Every word in a heading must be capitalized except for short minor words as listed in Section III-B.

The alunite-zones can be described macroscopically as light white to pink colored harsh material with extreme low 
hardness and no structure while under scanning microscopy alunite shows a dense, coarse crystal structure. Peaks at $3 \mathrm{~A}$ $(100 \%), 2.3 \mathrm{~A}(80 \%)$ and $2 \mathrm{~A}(70 \%)$ and especially in the area of $6 \mathrm{~A}(30 \%)$ and $5 \mathrm{~A}(60 \%)$ mark this clay mineral. In thermal analysis alunite has two endo -thermal reactions at $600^{\circ} \mathrm{C}$ and $800^{\circ} \mathrm{C}$ (Tab. 1).

Hydrothermal alteration near granites or rhyolites are predestine to build ore deposits like "dissiminated or porphyry copper ores" [6]. According to alunite occurrence in kaolin deposits can be used as indicator for more staged hydrothermal phases, ore phases as well as hypogenous and supergenous processes [7]. Nevertheless supergenous processes have just a small effect. It is supposed that there will be no further rejoin in Halakabad deposit.

\section{CONCLUSIONS}

Using the adsorption data, the reactions at the clay water interphase and the probable effects on the physical properties and structure of kaolinite are discussed. Pyrophyllite can also be used in the synthesis of ultra hard materials and as substituting material for talc in cosmetic and pharmacy industry [8-9]. Even in paper industry a market could be opened for kaolinite. But the mineralogical analyses are not enough to make sure reports for a selected mining. After the results of different analytic methods are compared, it could be considered the macroscopic field method and light microscopy are efficient methods for distinguishing pyrophyllite from kaolinite [10]. The exploration processes can be also controlled by these methods too[11]. Furthermore the results of XRD show the existence of 3 types of clay minerals in Halakabad deposit.

\section{REFERENCES}

[1] Hashemi, S.M, Vosooghi abedini ,M.,Khakhzad,A.Genesis of Bentonite in acidic tuffs of Shotori range volcanism (East of Tabas)in Proc. 14 international crystallography and mineralogy of Iran conference - Ferdowsi Uni. Mashhad, Iran 2007.paper no.233,P.345.

[2] Gorbani, M .,Arzani, K. Kaolin and fireproof clays, Geological Sur. of Iran,Rep.16,1994.

[3] Davis, F.,(1985),SME Mineral processing Hand book,V.2.PP.22-29

[4] Baccour, H. , Medhioub, M., Jamoussi, F., Mhiri, T., Daoud,A., Mineralogical evaluation and industrial applications of the Triassic clay deposits, Southern Tunisia ,Materials Characterization, Volume 59, Issue 11, Pages 1613-1622,November2008.

[5] Ian J. Ferguson, Johannes P. Ristau, Virginia G. Maris, Ifti Hosain, Geophysical imaging of a kaolinite deposit at Sylvan, Manitoba, Canada, Journal of Applied Geophysics, Volume 41, Issue 1, Pages 105-129, February 1999.

[6] Javier Huertas, José Linares María Bentabol, María Dolores Ruiz Cruz, Francisco, Chemical and structural variability of illitic phases formed from kaolinite in hydrothermal conditions ,Applied Clay Science, Volume 32, Issues 1-2, Pages 111-124, April 2006.

[7] Jorge C. Miranda-Trevino, Cynthia A. Coles, Kaolinite properties, structure and influence of metal retention on $\mathrm{pH}$, Applied Clay Science, Volume 23, Issues 1-4, Pages 133-139,August2003.

[8] J. Kroos, J. Kasbohm, Lethi lai, Pyrophyllite deposit in Tan Tanmai, Vietnam, ,Institute of Geological Sciences, VAST, Hà Nội,1999.

[9] G. J. Churchman, B. K. G. Theng, Clay research in Australia and New Zealand, Applied Clay Science, Vol. 20, Issues 4-5, pp. 153156, January 2002.

[10] P. Chiozzi, V. Pasquale, M. Verdoya, Radiometric survey for exploration of hydrothermal alteration in a volcanic area ,Journal of Geochemical Exploration, Volume 93, Issue 1, Pages 13-20, April 2007.

[11] Hashemi,S.M., Clay Minerals Reserve in Volcanic Rocks of South East Gonabad (East of Iran), in proc. International Conference of Cities on Volcanoes 6th, 2010,Tenerife,Spain,paper3.o-1.p.207. 